\title{
SPATIAL PATTERNS OF VOTING IN BUCHAREST AT THE EUROPEAN AND PRESIDENTIAL ELECTIONS OF 2019
}

\author{
Giorgian GUȚOIU, PhD
}

Lucian Blaga University of Sibiu, Romania

giorgian.gutoiu@ulbsibiu.ro

\begin{abstract}
The electoral year of 2019 was an important milestone in the recent Romanian democratic past. The European election held in May generated a turnout higher than at the previous three EP elections and higher than recent national parliamentary elections. Following this election that brought a strong defeat for the rulling party, the National Liberal Party left the opposition and formed a new cabinet. At the presidential election held in November, Klaus Iohannis the candidate of the National Liberal Party won a second consecutive term. In the present paper, the results at these elections are spatially analysed in the capital city of Bucharest. The aim of the paper is to examine the spatiality and the spatio-temporal realignments in the electoral behaviors in Bucharest, in order to bring a contribution to the understanding of the two elections, their unfolding in Bucharest, the electoral base of the three main actors of Romanian politics in Bucharest and the study of electoral behaviors in a large urban context. The results found important spatial patterns within Bucharest electoral geography that largely reflect the contrasting socio-spatiality of the city and the position of parties within the political arena. The analysis also revealed spatio-temporal realignments in the electoral geographies at these elections which point to the necessity to account for the political, social and economic geographic context of the election in order to better understand the spatiality of voting behavior in a shifting electoral geographic landscape.
\end{abstract} \section{Bucharest.}

Keywords: Romanian European election 2019, presidential election, electoral geography,

\section{Introduction}

In 2019, in Romania a change in power occured after two important elections were held that year. European elections were held on 26 of May generating a higher turnout than in previous European elections and a massive protest vote against the Social Democratic Party (PSD, Partidul Social Democrat) - the incumbent party since 2016. These results were highly important since previous studies on European elections in EU have shown that these elections generally produce lower turnout than national legislative elections due to the fact that voters see them as second- 
order elections (Reif and Schmitt, 1980; Hix and Lord, 1997; Schmitt and Teperoglou, 2015). However, the Romanian elections confirmed the literature which states that European elections may generate levels of turnout according to their location within the national cycle of elections (Hix and Marsh, 2007). When European elections are closer to the end of the cycle, voters use these elections to evaluate and punish the ruling parties. The European elections in Romania were held the same year as the presidential run and a year before the national legislative elections. In October 2019, PSD was replaced as the rulling party by the National Liberal Party (PNL, Partidul National Liberal) which won the European elections. At the presidential elections held in two rounds (10 and 24 November) Klaus Iohannis from PNL won its second consecutive term for another five years, after defeating Viorica Dăncilă, the leader of PSD and prime-minister between 2018-2019. In this paper, I analyse the electoral geographies at these elections in Romania's capital city - Bucharest. The European elections in Bucharest resulted in a landslide victory for a third actor, the alliance formed by the Save Romania Union (USR, Uniunea Salvați România) and the Party of Liberty Unity and Solidarity (PLUS, Partidul Libertății Unității și Solidarităţii). USR-PLUS alliance is highly urban-oriented. In Bucharest, PNL came third closely behind PSD. Iohannis won the presidential election in Bucharest (both rounds). The candidate of USR-PLUS, Dan Barna, came second while on the third place was Dăncilă.

The aim of the paper is to examine the spatiality and the spatio-temporal realignments in the electoral behaviors in Bucharest, in order to bring a contribution to the understanding of the two elections, their unfolding in Bucharest, the electoral base of the three main actors of Romanian politics in Bucharest and the study of electoral behaviors in a large urban context. The approach is underpinned by developments in the subfield of electoral geography, where a major topic of research is the spatiality of voting (Leib and Quinton, 2011). The paper extends the current literature on Romanian spatial voting patterns (Giugăl, Johnston and Constantinescu, 2011; Guțoiu 2018, 2019a). Although the electoral geography approach is largely quantitative and empiricist, within the literature there are some ussually suspect variables used to explain the spatial variation of voting - political actors, voters and the local context (Agnew, 1996; O'Loughlin, Flint and Anselin, 1994; Johnston and Pattie 2006). In this regard, the first section of the paper describes the political context of the two elections at both national and local scale, while the second describes the social and economic geography of Bucharest. Afterwards, the statistical tools employed for 
spatial analysis of electoral data are described. The spatial analysis is divided into two sections, dealing with each election in turn.

\section{Political context}

During the $90 \mathrm{~s}$ and the 2000s, at the forefront of Bucharest politics were the liberal and pro-western political parties that opposed PSD, the main succesor of the former communist party (Pop-Elecheș, 1999, 2008). In the 90s, in Bucharest there were strong popular anti-communist feelings. Many civic mass protests developed against the succesor party which won all the national elections in 1990 and 1992. During the 1996-2000 period, the liberal parties governed but they were perceived as unskilled and were hit by economic voting and also lost their support in Bucharest. The early 2010s economic crisis brought more dissatisfaction towards the liberal parties because of their austerity measures. In this context, during the last two decades PSD won mayoral seats and majorities in councils at the municipal level and in Bucharest's six subdivisions (sectors). At the local and legislative elections of 2016, in Bucharest and nation wide, PSD which has an electoral base formed mostly of vulnerable social categories won a landslide victory in the context of a low mobilization in main urban areas. At the legislative elections of 2016, at the national level, PSD won $46 \%$ of votes, PNL $20 \%$ and USR only $9 \%$. In Bucharest, PSD won fewer percentages, namely $38 \%$, USR $25 \%$ and PNL 12\%. The much higher percentage score by USR in the capital city is explained by the profile of USR which formed earlier that year as a regional party based in Bucharest. These three parties are the main actors also at the 2019 elections.

In February 2017, shortly after they started governing, PSD raised widespread popular discontent when the cabinet tried to decriminalize certain corruption deeds for which some of the party leaders could have gone to jail. Dissatisfaction was also enhanced by the way the government enacted the law through a decree during nightime. In Romania (Crețan and O'Brien, 2020), as well as in other parts of Central and Eastern Europe (Hanley and Sikk, 2014; Sikk, 2012), the anticorruption became a central topic for the public opinion, so the sensitivity of the citizens to this topic generated frequent loss of popular support for the big political parties often accused of corruption. The popular anti-corruption and anti-government in Romania were highly strong during the early 2017, but they also continued into the 2018. At their peak, the protests gathered an impressive number of nearly 500,000 protesters nationwide. The usual protester was young and educated, and dissatisfied with the government policies that could have endangered Romania's 
path as a democratic country within the European Union. These were grass-roots movements, as neither PNL or USR managed to raly the protesters.

From 2017 and up to the European elections, PSD dropped massively in the polls. This downfall favoured the parties in opposition, PNL and USR which tried to mobilize through an anticorruption, anti-PSD and pro-European rhetoric. During the campaign for the European elections, PSD used an anti-European and sovereignist rhetoric that raised concerns among Romanians of a possible exit from the Union. The main actors at the European elections were PSD and its opposition, namely PNL and USR, the latter running in an alliance with the PLUS, a nonparliamentary party leaded by Dacian Cioloș, a former prime-minister known for its pro-EU stances.

The results and the turnout at the European elections are displayed for both Bucharest and national level in Table 1. I analyse the electoral geographies of the first three actors. In the table are displayed also the results for two other minor parties for a better understanding of the political context - the Popular Movement Party (PMP, Partidul Mișcarea Populară) supported by educated conservatives and former catch-all voters of Băsescu and Pro Romania supported mainly by those social vulnerable. At both scales, the results display a massive protest vote against PSD, which loses almost a half of its votes from 2016. In Bucharest the ranking was quite different from the national one. As USR-PLUS scored a landslide victory with 41\%, in Bucharest both PSD and PNL are below their national average. Both USR-PLUS and PNL rallied voters against PSD.

Table 1. Results at the European election

\begin{tabular}{l|llc} 
& Bucharest & National & $\begin{array}{c}\text { Difference } \\
\text { (Bucharest - National) }\end{array}$ \\
\hline USR-PLUS & $40.62 \%$ & $22.36 \%$ & $18.26 \%$ \\
PSD & $16.68 \%$ & $22.50 \%$ & $-5.82 \%$ \\
PNL & $15.76 \%$ & $27.00 \%$ & $-11.24 \%$ \\
PMP & $8.14 \%$ & $5.76 \%$ & $2.38 \%$ \\
Pro Romania & $6.87 \%$ & $6.44 \%$ & $0.44 \%$ \\
turnout & $51.46 \%$ & $49.65 \%$ & $1.81 \%$
\end{tabular}

Source: Values computed by the author using official electoral data from http://alegeri.roaep.ro 
The anti-PSD rhetoric continued also after the European elections. A few days after the elections, Liviu Dragnea, the leader of PSD, is arrested for corruption allegations but the party continues to stay in power up to October. The new party leader becomes Dăncilă, the first woman to serve as Prime-Minister since 1990, and PSD's candidate at the presidential elections. Her main contestant was the acting president, Klaus Iohannis from PNL. Iohannis, a German ethnic, won the 2014 elections by defeating PSD's candidate with a large support from the pro-European and reformist strata. In 2019, within the context of the deep popular dissatisfaction with PSD government, it became clear before the elections that Iohannis would win by a large margin. The other important candidate was Dan Barna the leader of USR.

Two rounds of election were held in November 2019 to elect a new president. The results at these rounds in Bucharest and national level are displayed in Table 2. For a better understanding of the context, the table also shows the results for two other candidates, meaning Mircea Diaconu from Pro Romania and Theodor Paleologu from PMP. At the presidential election, the turnout was similar to the one at the European elections, which was unusual for the relationship between the two elections. In both rounds, and at both scales, Iohannis ranked first. At the national level, on the second place was Viorica Dăncilă. A few days before the first round, PSD government colapsed, and a new cabinet was formed by PNL. In the second round, Iohannis won a landslide victory. The score of Dăncilă in the first round is similar with PSD's in European elections. Iohannis has a better score than PNL (at both rounds), while Barna has fewer votes than USRPLUS (at both scales, but mainly in Bucharest with a 16\% drop). Given that USR-PLUS was close to PSD at the European elections, before the presidential election the public opinion expected a second round fought between Iohannis and Barna, and so for the first time in post-communist Romanian politics a second round of presidential elections without the candidate from PSD. However, in the first round, Barna won fewer votes than USR-PLUS at the European elections. The explanation is that, typically, in the European Parliamentary elections, smaller parties tend to gather more votes than in first-order elections, at the expense of the major parties (Hix and Marsh, 2011). Also, Barna was viewed by USR-PLUS's electorate as a rather uncharismatic leader. 
Table 2. Results at the Presidential election

\begin{tabular}{|c|c|c|c|c|}
\hline & & Bucharest & National & $\begin{array}{l}\text { Difference } \\
\text { (Bucharest } \\
\text { National) }\end{array}$ \\
\hline \multirow{6}{*}{1 st round } & Klaus Iohannis (PNL) & $31.77 \%$ & $37.82 \%$ & $-6.05 \%$ \\
\hline & Dan Barna (USR-PLUS) & $24.83 \%$ & $15.02 \%$ & $9.81 \%$ \\
\hline & Viorica Dăncilă (PSD) & $17.90 \%$ & $22.26 \%$ & $-4.36 \%$ \\
\hline & Mircea Diaconu (ALDE and ProRomania) & $11.30 \%$ & $8.85 \%$ & $2.45 \%$ \\
\hline & Theodor Paleologu (PMP) & $8.07 \%$ & $5.72 \%$ & $2.35 \%$ \\
\hline & turnout & $50.80 \%$ & $50.40 \%$ & $0.40 \%$ \\
\hline \multirow{3}{*}{2 nd round } & Klaus Iohannis (PNL) & $67.52 \%$ & $66.09 \%$ & $1.43 \%$ \\
\hline & Viorica Dăncilă (PSD) & $32.48 \%$ & $33.91 \%$ & $-1.43 \%$ \\
\hline & turnout & $53.14 \%$ & $53.86 \%$ & $-0.71 \%$ \\
\hline
\end{tabular}

Source: Values computed by the author using official electoral data from http://alegeri.roaep.ro

The European and presidential elections in Romania in 2019 were marked by the victory of PNL, the main opposition party, and the massive protest vote given to PSD, the rulling party, which suffered a major defeat in both elections. A third actor, USR-PLUS alliance appeared to be able to challenge the dominance of the two big parties of Romanian politics, but the good score obtained at the European Parliamentary elections was followed by Barna's failure to enter in the second-round at the presidential elections.

\section{Bucharest and its social and economic geography}

The social and economic geography of Bucharest, is the result of developments from three periods - pre World War II, state socialism (1948-1989) and post-socialist. During the socialist era, Bucharest went through big scale transformations under the massive industrialization and urbanization policies of the totalitarian state (Zarecor, 2018). Bucharest was the main unit in the state planned economy. At that time, Bucharest doubled its area and population, reaching almost two million inhabitants. Large collective estates are built throughout the city, the vast majority of these were erected outside the boundaries of the pre-1948 city (Maxim, 2009). In 2019, almost $80 \%$ of the houses in Bucharest were apartments built in the socialist era. However, the socialist 
spatial transformations were not present throughout the entire city. In the central area, the pre-WW II urban fabric is still present, an exception is the southern and central-southern space which was redesigned with large boulevards and blocks by the autocratic leader Nicolae Ceausescu (Cavalcanti, 1997; Maxim, 2019). The totalitarian regime didn't succeed in creating a monolithic and standardized urban socio-spatial. When the state socialism fell, Bucharest had important sociospatial segregations: between the socialist and historical central areas, between the socialist neighborhoods or at the lower level where the historical tissue was partially destroyed (Marcińczak and Hess, 2019; Marcińczak et al., 2014).

After the state socialism era, Bucharest gradually opened to the global circulation of capital. In this context Bucharest developed economically and demographic as the main growth pole of the country (Benedek and Cristea, 2014; Guțoiu 2019b). The free market starts creating strong social filtering between the large socialist housing estates which are not monolithic and tend to vary in quality and proximity to services. After the state led urban development during state socialism, in postsocialism and under the freemarket the Bucharest municipality avoids involvment in urban planning (with the exception of some large infrastructure projects) (Ion, 2014). The circulation of free capital during the last three decades created in Bucharest strong socio-spatial contrasts (Mionel and Neguț, 2011; Marcińczak et al., 2014; Rufat and Suditu, 2008). The richer groups are located in the low-density neighborhoods in the central city and the north. Many parts of the central historical city are increasingly becoming more gentrified. Outside the central city are the socialist estates. Their socio-spatiality is not uniformed. The vulnerable groups live in low-quality blocks with fewer public or private services in their proximity. In the socialist housing estates, richer groups or close to the median income live mainly in the following neighborhoods: Militari (West), Drumul Taberei (West), Berceni (South), Tineretului (CentralSouth) and Titan (East). The most poorer groups are clustered in the peripheric self-built homes or in the low-quality socialist apartments from the Rahova and Ferentari neighborhoods in SouthWest.

\section{Statistical tools for spatial analysis of electoral data}

In this section I describe the data, their processing and the statistical tools employed. The spatial analysis of the electoral patterns at these elections in Bucharest requires electoral data that is georeferenced. The electoral data are aggregated at the level of polling locations in Bucharest 
(European elections $\mathrm{N}=271$, presidential elections $\mathrm{N}=267$ ). The polling locations are mapped in geographic space as points corresponding to their geographic physical location.

A first part of the spatial analysis consists of discussing some general descriptive statistics. Firstly, I use non-geographic descriptive statistics that do not account for the geographical location of the voting behavior. In this regard, I analyse the distribution of electoral scores through common descriptive statistics, such as the mean, range and standard deviation. These non-spatial descriptive statistics are used as points of reference for the following spatial analysis. Also, as a part of descriptive statistics, but including a geographical dimension, I shall use choropleth maps with the distribution of electoral scores in four classes.

The main spatial statistical tools I employ for exploring the electoral data are based on measuring the degree of spatial autocorrelation, by accounting for the correlation between close observations in the geographical space (Griffith, 1987). Spatial autocorrelation, also known as spatial dependence, is best described by Waldo Tobler's first law of geography: everything is related to everything else, but near things are more related than distant things (Tobler, 1970). Spatial autocorrelation shows the geographic clustering of electoral performances and in the present analysis it is measured at two geographic levels: global, for the whole city, and local, corresponding to local clusters of support consisting of a small number of polling location. Moran's I is the common instrument to measure global spatial autocorrelation and is expressed as:

$$
I=\frac{\Sigma_{i} \Sigma_{j} w_{i j}\left(x_{i}-\bar{x}\right)\left(x_{j}-\bar{x}\right)}{\Sigma_{i}\left(x_{i}-\bar{x}\right)^{2}}
$$

where $x$ is the electoral score for candidate of interest, and $w$ is a component in the rowstandardized spatial weights matrix (W). The relations of proximity between observations are summarized within this spatial matrix on the basis of a binary situation, i.e. 1=connection and $0=$ disconnection. To compute the vicinity between observation I employ a queen contiguity-based definition. Moran's I takes values from -1 (perfect dispersion) to +1 (perfect clusterization). A zscore is used to asses the statistical significance. For a positive statistical significant spatial autocorrelation the z-score should be over 1.96. I compute both the Moran's I and z-score using the free software GeoDa designed for spatial analysis. Local spatial patterns are identified using 
the Local Moran's I function in GeoDa, which is a Local Indicator of Spatial Association (LISA) (Anselin, 1995) and is expressed as:

$$
I_{i}=\frac{z_{i}}{\sum z_{i}^{2}} \sum_{j} w_{i j} z_{j}
$$

where $z$ is computed as standard deviations from the mean. The inference is verified through a similar method of randomization as for Global Moran's I. However, since LISA is computed for each observation, the statistical significance test is computed for each observation and its neighbors. GeoDa computes the LISA, runs the significance test and identifies one of the following four types of spatial association regimes: 1) clusters of high values surrounded by high values; 2) clusters of low values surrounded by low values; 3 ) outliers of low values surrounded by high values and 4) outliers of high values surrounded by low values. The level of significance employed to identify the clusters is 0.05 .

In this section the statistical tools employed for spatial analysis of electoral data were described. Four instruments are used: non-geographic descriptive statistics, quantile maps, Global Moran's I and LISA cluster maps. The rest of the paper proceeds with the spatial data analysis.

\section{Spatial voting patterns in Bucharest}

\section{European election}

The aim in this section is to analyse the spatial voting patterns in Bucharest at the 2019 European elections. Table 3 shows the non-geographic descriptive statistics that can be used as points of reference for the spatial analysis. In Bucharest, the election was won by USR-PLUS by a large margin. On the second and third place were the two big parties of Romanian politics: PSD, which was the rulling party at that time and was hit by a strong protest vote, and PNL which won by a few percentages the election at national level. USR-PLUS has the highest standard deviation (6.4) and the largest range of values. Scores vary between locations, but at a much lower level for PSD. The lowest deviation is for PNL, although its $10 \%$ range of values is considerable. 
Table 3. Descriptive statistics in Bucharest at the European election

\begin{tabular}{l|llll} 
& Maximum & Minimum & Mean & $\begin{array}{l}\text { Standard } \\
\text { Deviation }\end{array}$ \\
\hline USR- & $72.72 \%$ & $19.68 \%$ & $40.62 \%$ & 6.4 \\
PLUS & & & & \\
PSD & $34.45 \%$ & $4.17 \%$ & $16.68 \%$ & 3.3 \\
PNL & $22.41 \%$ & $9.36 \%$ & $15.76 \%$ & 1.8
\end{tabular}

Source: Values computed by the author using official electoral data from http://alegeri.roaep.ro

Further, I analyze the quantile maps in Figure 1 which consists of quantile scores maps for each of the three actors, one map with the winner in each location, and the maps with ratio values between scores. USR-PLUS wins across the entire city (267 of 271 locations), but with strong spatial variations. The quantile maps display the geographic distribution of electoral results. Spatial patterns of electoral support for USR-PLUS are well defined. Higher scores are located in the central gentrified area and on the north-south and west-east development axes. These latter spaces are filled with the large socialist housing estates of medium and higher quality. It is here that the majority of USR-PLUS electoral base lives, namely those young and educated, with a high part of them living in rent. Some of alliance's top 5\% performances were recorded in the student campuses. Poorer performances were recorded in the vulnerable and marginalized sociospatialities, located at the outskirts of the city.

USR-PLUS did poorer in the same places where PSD recorded its higher scores. These are the low-quality socialist estates and the low quality self-built homes with defficient accesibility to public services. These places are located at all the outskirts of the city, except in the northern and north-western richer parts. The electoral geography of PSD is in opposition with the geography of USR-PLUS, so the places where PSD did poor are the same places where USR-PLUS achieved landslide victories.

Although PNL won the election at the national level, in Bucharest PNL ranked only second or third in every locations. The disperssion and range of values are lower for PNL, but its quantile maps display geographic clustering of patterns of spatial support or lack of support. The electoral geography of PNL has similarities with both geographies of USR-PLUS and PSD. Locations with 
higher scores of PNL in the first or second upper quantile are either spaces of strongholds for USRPLUS in the gentrified central city or in the richer north or marginal poorer spaces favourable also towards PSD. Locations in PNL's lower quantiles are scattered throughout the city, however most of them are located in the average quality socialist estates where USR-PLUS recorded its best performances.

Figure 1. Quantile maps at the European election

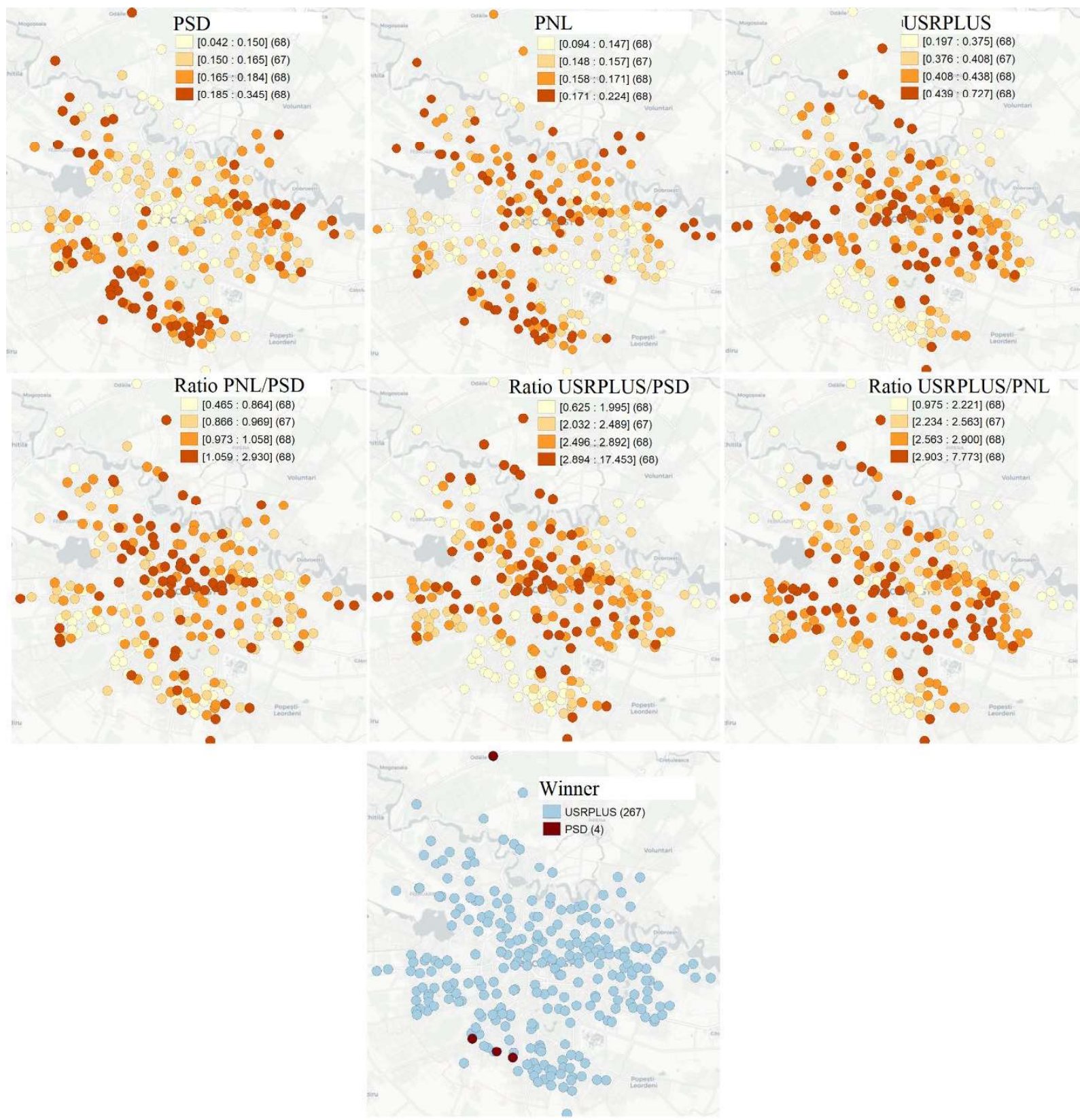

Source: Values computed by the author using official electoral data from http://alegeri.roaep.ro 
Although quantile maps show the geographic distribution of votes, these maps do not offer an exact measure of spatial polarization and do not localize the statistically significant clusters of support or lack of support. In this regard, I use Moran's I to measure the degree of spatial autocorrelation. Table 4 displays the values of Global Moran's I for candidates of interest. The values indicate a polarized geographic space with solid spatial patterns. There is a major clusterization for USR-PLUS, and average polarization for PSD and PNL. This indicates that each of the three actors had a well-defined spatial electoral base. Although the standard deviation is greater in the scores for PSD and PNL, the Moran's I displays similar global clusterings for the two parties. Further, for the analysis of local patterns I employ LISA.

Table 4. Moran's I values at the European election

\begin{tabular}{l|cc} 
& Moran's I & z-score \\
\hline USR-PLUS & 0.52 & 13.93 \\
PSD & 0.34 & 9.87 \\
PNL & 0.36 & 10.83
\end{tabular}

Source: Values computed by the author using official electoral data from http://alegeri.roaep.ro

LISA maps for actors of interest are shown in Figure 2. These maps identify local clusters of support, lack of support or outliers. For all actors there are polarized electoral geographies, with well-articulated spatial patterns that reflect the socio-spatial contrasts of Bucharest. The most polarized map is for USR-PLUS. High-high clusters are located in the northern area with pre-WW II villas, suburbs and green spaces, in the gentrified central city, in the student campuses, and in the average quality socialist collective housings (the neighborhoods Militari and Crângași in the west, the Aviation in the north) or the high quality socialist housings in the central city. Clusters of low-low support are located at the socio-spatial peripheries of the city, mostly in the neighborhoods Rahova and Ferentari in the south-west. Other clusters of small support are located at the north-western periphery (neighborhoods Giulești and Chitila) and the eastern periphery (neighborhoods Andronache and Industriilor). USR-PLUS electoral geography is polarized and its electoral base is underpinned by the richer, younger and educated groups.

The electoral geography of PSD is in opposition with USR-PLUS map. The spaces where the alliance did better, PSD has clusters of low scores, while the hotspots for PSD are the places 
of weak scores for USR-PLUS. Hot-spots of high values for PSD are located at the socio-spatial peripheries, most of them in the south-western neighborhoods of Rahova and Ferentari. Low-low clusters are scattered throughout the city, in the inner gentrified ring, student campuses, middle class suburbs in the south and north and in the upper class spaces from the north.

Both USR-PLUS and PNL based their electoral strategy on mobilizing the anti-PSD and anti-government voters. However, both these two actors, have electoral geographies with significant differences between them. PNL has in many places an electoral geography that is in opposition with USR-PLUS. Clusters of high support for PNL are located in peripheric areas where USR-PLUS scored its lowest performances and PSD its best ones. This means that PNL colonized the same places as PSD. Although PNL itself is positioned as a liberal and non-populist party, PNL captured many votes in poorer places that are not typical for such parties. This situation was due to the high protest vote and dissatisfaction towards PSD in these places. High-high clusters of PNL are more numerous at the periphery. In the central gentrified area, the map of PNL is mixed, with outliers, and hotspots of both low and high performances. For this reason, PNL map is not entirely in opposition with USR-PLUS. Clusters of low support are located in the collective housings with younger groups that voted for USR-PLUS.

Figure 2. LISA maps at the European election

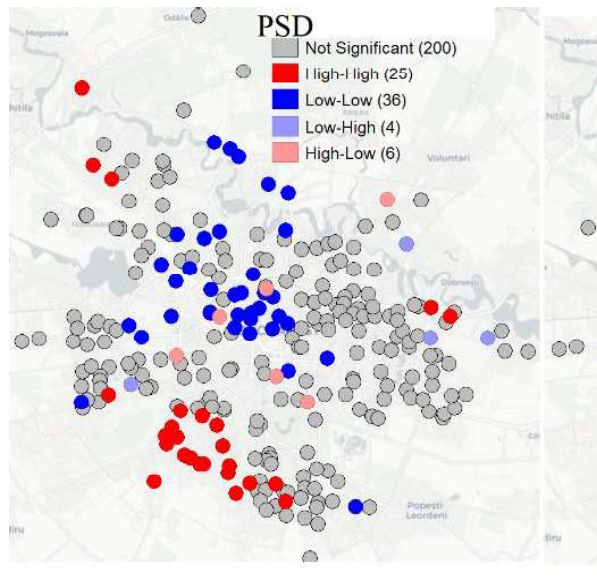

Source: Values computed

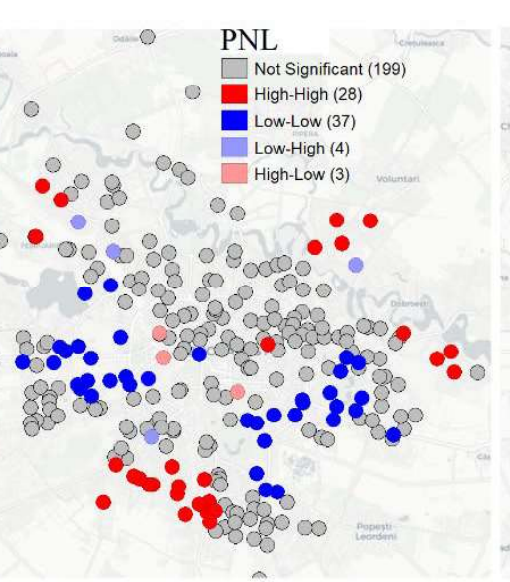

by the

http://alegeri.roaep.ro 
The alliance won the election in Bucharest by mobilizing throughout the entire city more than the other two parties did. The analysis in this section revealed how USR-PLUS constructed an electoral base in opposition against PSD. USR-PLUS was much stronger in places with younger and educated groups, while PSD had higher shares in places with poorer groups. PNL, the main opposition party which also took advantage of anti-PSD protest vote, had a distinct electoral geography than the alliance by colonizing spaces of PSD. In the following section I shall also compare the patterns at the presidential election with the one at the EP election in order to better grasp the spatio-temporal electoral realignments.

\section{Presidential election}

The two rounds of presidential election were held about six months after the EP ones. As we shall see, the time elapsed between the two generated some important realignments. The methodological structure of the analysis in this section is similar to the previous one - an initial discussion on descriptive non-geographic and geographic statistics and afterwards the analysis of global and local spatial patterns autocorrelation.

Descriptive statistics for both two rounds are shown in Table 5. In Bucharest, in the first round, Dăncilă (PSD) ranked second, whilst Barna (USR-PLUS) ranked third. Both Iohannis and Dăncilă did better than their parties, while Barna had a lower score than the alliance. The extreme values of Iohannis range of results is higher than PNL's, while the range is constant at 13\%. This points to a proportional increase for Iohannis in comparison with PNL, within the context of Barna's lower results than USR-PLUS. The range in Barna's scores is indeed wide, but it is much narrow than that of USR-PLUS, even though Barna has the highest standard deviation among the three candidates. The range in Dăncilă's scores is relatively wide, but has the same values as for PSD. The high range (43\%) and standard deviation (5.1.) in the results of the secound round both indicate a polarized electoral space. 
Table 5. Descriptive statistics in Bucharest at the Presidential election

\begin{tabular}{ll|llll} 
& & Maximum & Minimum & Mean & Standard Deviation \\
\hline \multirow{3}{*}{ 1st round } & Iohannis & $37.86 \%$ & $24.63 \%$ & $31.77 \%$ & 2.0 \\
& Dăncilă & $35.15 \%$ & $4.19 \%$ & $24.83 \%$ & 3.6 \\
& Barna & $46.83 \%$ & $11.75 \%$ & $17.90 \%$ & 4.8 \\
\hline \multirow{2}{*}{ 2nd round } & Iohannis & $89.59 \%$ & $47.44 \%$ & $67.52 \%$ & 5.1 \\
& Dăncilă & $52.56 \%$ & $10.41 \%$ & $32.48 \%$ & 5.1
\end{tabular}

Source: Values computed by the author using official electoral data from http://alegeri.roaep.ro

Quantile maps for both rounds of election are shown in Figure 3. Firstly, I shall discuss the maps for the first round. The map which depicts the winner in each location is dominated by Iohannis who won in $91 \%$ of the locations. These results are completely different from those at the EP where PNL failed at every location to rank as the first party. Barna ranked first in 20 locations, in places with larger groups of young and educated adults, the same places where USRPLUS recorded its best scores. Dăncilă ranked first only in 3 locations, all with mainly poorer population. The geographic distribution of votes for Iohannis is highly scattered and expands on a wider range of social and geographic milieux than it was the case for PNL at the European election. The better scores are once again recorded at the social and geographic peripheries. However, unlike PNL, Iohannis performance at the peripheries is less extensive since he also gains high scores in richer areas (central and north) and in the large socialist housing estates, however not those with larger groups of younger adults (Drumul Taberei in the west, Pantelimon in the east, and Colentina in north-east). The quantile map for Dăncilă is similar to the one for PSD. The locations in the higher quantiles are in the peripheral areas with vulnerable populations, and the lower scores in the locations with richer and younger populations. The electoral geography of Barna, likewise that of USR-PLUS is developed in opposition with the one of PSD and its candidate. Barna's geographic distribution is similar to USR-PLUS, and for this matter the decrease in percentages, in comparison with the alliance's scores, is proportionally distributed across the city. Quantiles of high scores for Barna are located mostly in central places with younger, richer groups, whilst the 
quantiles with low performances are located at the peripheric areas where Dăncilă scored her best results.

In the map depicted to show the results for the second round we see the landslide victory of Iohannis, who won in $99 \%$ of locations. Within this victory there are some important spatial patterns. Iohannis has at least two times more votes than his opponent in the socialist housing estates with younger population, in the gentrified areas, in the richer north and the car-based suburbs. Smaller differences between Iohannis and Dăncilă we find in the poorer areas — the socio-spatial peripheries of the south-west, south, north-east, north-west — and the socialist housing estates with older population. The electoral geography of Dăncilă in the second round is similar to her geography in the first round and that of PSD. However, the geographic distribution for Iohannis in the second round is different from his geography in the first round and that of PNL. In the second round, the high scores are outside of the peripheric areas. The geography of Iohannis has many similarities with the one of USR-PLUS. The following global spatial autocorrelation wil show the geographic clustering of voting in order to better grasp the electoral geographies at the presidential election and the realignments between the EP and presidential elections.

Figure 3. Quantile maps at the Presidential election

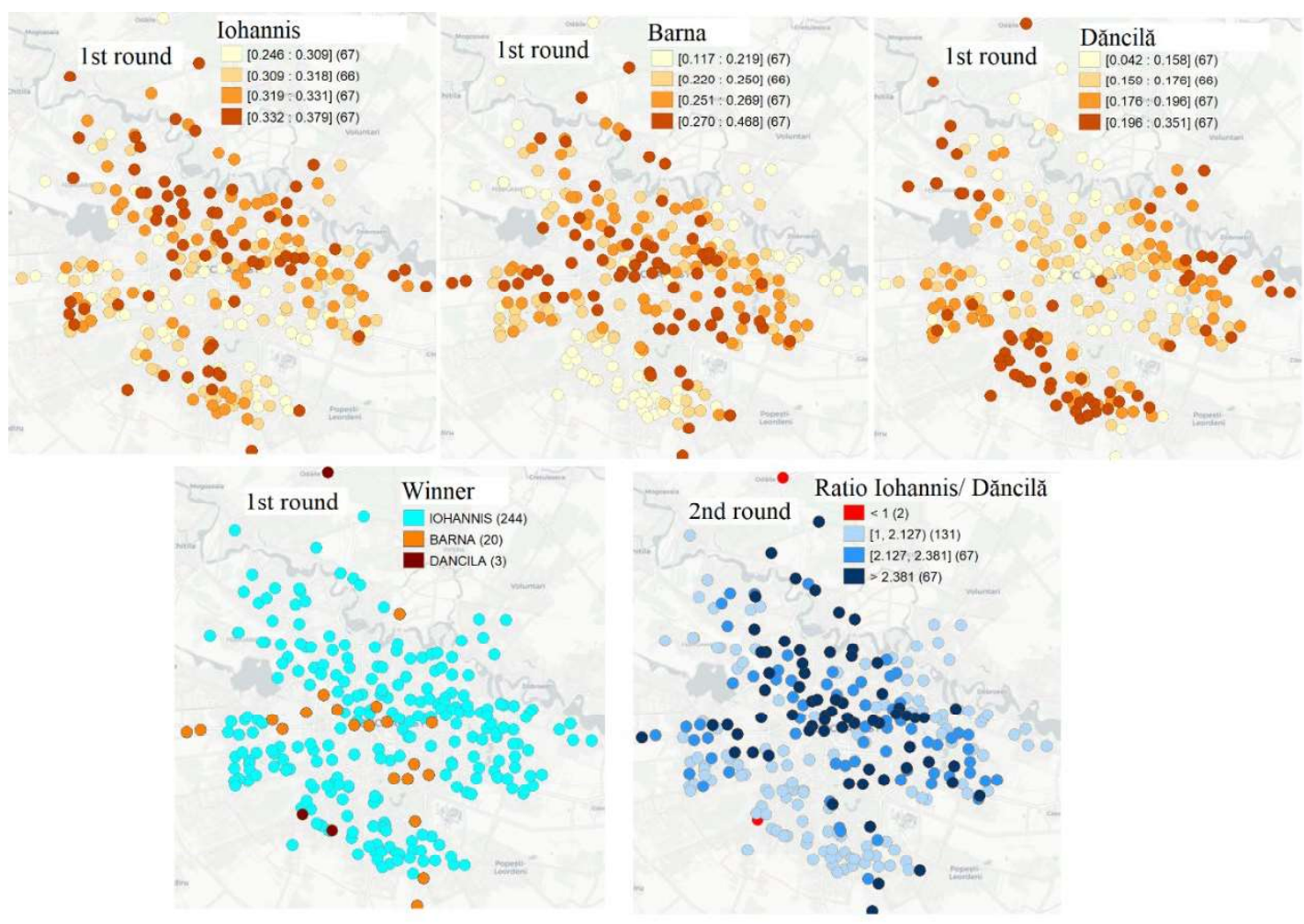

Source: Values computed by the author using official electoral data from http://alegeri.roaep.ro 
The Moran's I and z-scores at both rounds are depicted in Table 6. The spatial autocorrelation for Dăncilă and Barna has medium to high strength. We find a medium to low degree of polarization at the candidates in the second round. In the first round, Iohannis electoral geography has a low degree of spatial polarization. This finding is consistent with the idea of an electoral geography developed as a result of a catch-all rhetoric directed towards many sociospatialities. For Dăncilă the polarization is slightly higher than that of PSD, while for Barna the spatial polarization is slightly lower than that of USR-PLUS, however the differences are relatively small. Generally, the competition at the presidential election generated a lower degree of spatial polarization than the EP election. This development also indicates a less polarized political competition. This also explains why the presidential election generated a turnout similar to that of the European elections. The presidential election of 2019 was a contest with known winner. The landslide victory was also no surprise. The radicalized vote that was present at the EP election was now only partially present.

Table 6. Moran's I values at the Presidential election

\begin{tabular}{l|l|ll}
\multicolumn{2}{l|}{} & Moran's I & z-score \\
\hline \multirow{2}{*}{$\begin{array}{l}\text { 1st } \\
\text { round }\end{array}$} & Iohannis & 0.17 & 4.81 \\
2nd & Barncila & 0.42 & 11.68 \\
round & Ratio Iohannis/Dăncilă & 0.47 & 13.23 \\
& & & 8.23
\end{tabular}

Source: Values computed by the author using official electoral data from http://alegeri.roaep.ro

The LISA maps for results at the first and second round are displayed in Figure 4. Of all the candidates, Iohannis has the most scattered electoral geography with the lowest degree of clusterization. This finding is consistent with the low global clusterization since the global Moran's I is the sum of local clusters. The electoral geography of Iohannis in the first round is more scattered than that of PNL -46 clusters for Iohannis vs. 66 for PNL. However, Iohannis electoral geography still presents some clear patterns of spatial clusterization. High scores are located in the 
richer northern areas, in the low-density suburbs and partially in the city centre. Low scores are located in a large range of socio-spatialities, which are mainly simpathetic towards USR-PLUS or PSD - the city centre, socialist housing estates with younger population and the poorer neighborhoods of Rahova and Ferentari. Clusters of Iohannis in the first round are located in other places than those of PNL. The party was stronger at the peripheries, whilst Iohannis was stronger in richer areas, that were contained in USR-PLUS map of high-high scores.

Figure 4. LISA maps at the Presidential election

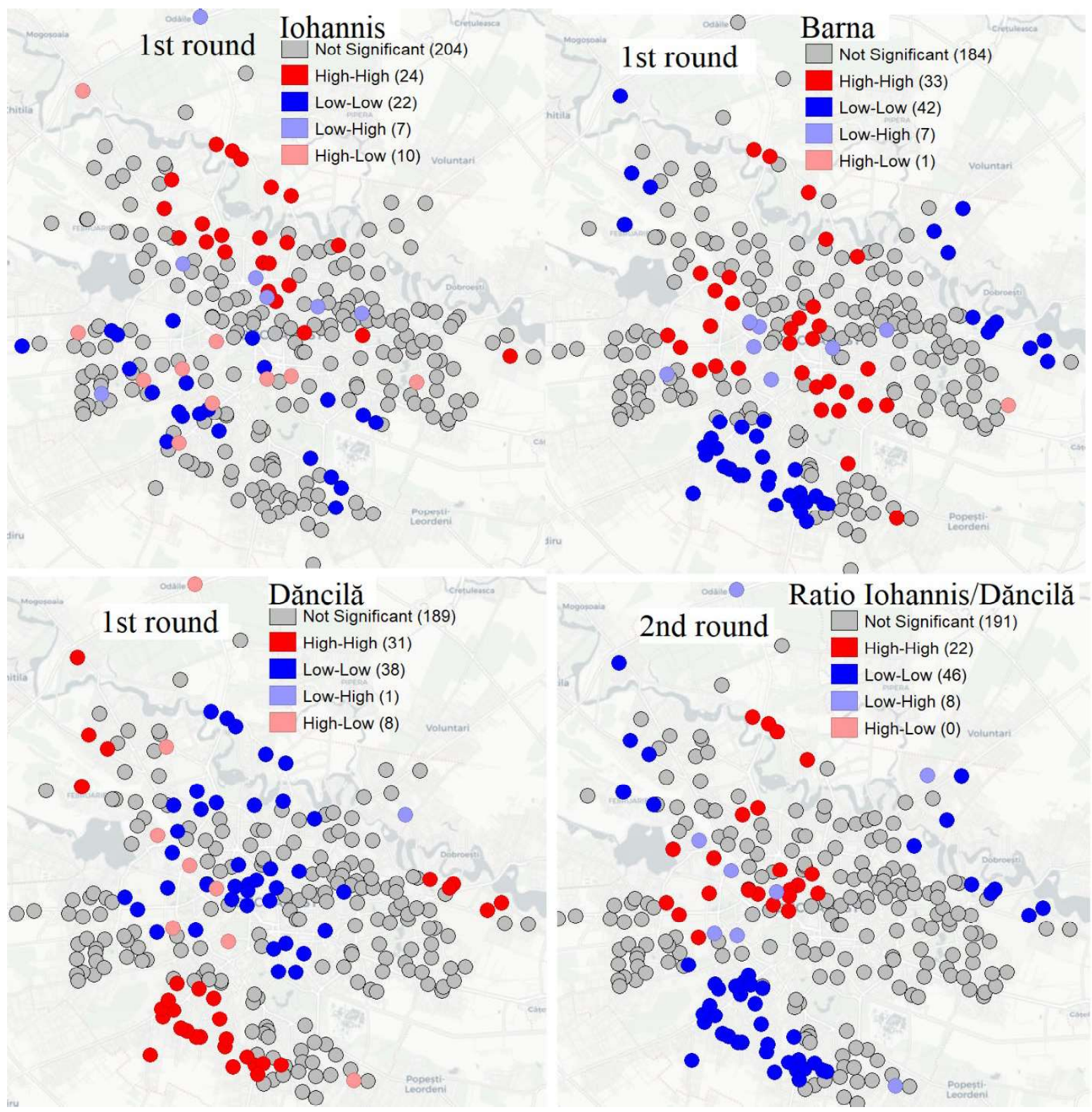

Source: Values computed by the author using official electoral data from http://alegeri.roaep.ro 
Dăncilă's score in the first round is similar to the one of PSD. Similarities are present also between the two electoral geographies. Clusters of high support or lack of support for Dăncilă are the same as those of PSD. The high-high clusters are located in peripheric area, whereas low-low clusters are located in central gentrified areas, in the north and in the student campuses. Findings show that are no major realignments in the relation between the geographies of PSD and Dăncilă.

The spatiality of clusters for Barna is similar to the one of USR-PLUS. Clusters of highhigh support are located in areas where younger, educated, and affluent population is located, while the low percentages are clustered at the socio-spatial peripheries. His lower performances in comparison with the ones of USR-PLUS are explained by the spatially proportional distributed realignment of voters and the colonization of geographic space by Iohannis.

Figure 4 also displays the LISA map for second round based on ratio votes between Iohannis and Dăncilă. There are clusters of spatial polarization identified within the map. Clusters of high-high are areas where the difference between Iohannis and Dăncilă was bigger. Such clusters are located in the central area, in student campuses and the northern areas. Although he achieved a landslide victory in these spaces, Iohannis has an electoral geography with an important catch-all twist, since his electoral base was formed also on high scores recorded in mixed sociospatialities of the socialist housing estates. Clusters of lower differences between the two candidates or locations where Dăncilă won more votes than Iohannis are located at the sociospatial peripheries.

In Bucharest, the presidential election was won with a landslide victory by Iohannis. His success is explained by the protest catch-all vote against Dăncilă and her party. Moreover, Iohannis gathered support that previously at the EP election was directed towards USR-PLUS alliance but now wasn't successfully capitalized by Barna. As a consequence of this realignment, Barna ranked third, by a lot below the alliance's score at the EP election. Dăncilă's electoral geography is similar to the one of PSD, as the support is higher at the peripheral socio-spatialities.

\section{Conclusion}

In this paper, the objective was to explore and understand the electoral geographies of Bucharest at two important elections in the recent history of Romanian politics - the 2019 European Parliamentary and national presidential elections. The European elections in May 
through a protest and economic vote generated a change in power at the top of Romanian politics, contributing to the fall of PSD-led government, which has been in power since 2016. European Parliamentary election in Romania had a high turnout, bigger than at previous EP and national legislative elections. The presidential election in November continued on the path of anti-PSD voting, giving a landslide victory to Klaus Iohannis who won a second consecutive term, running for PNL, the party that had previously won the EP election and at the time was in power. In Bucharest, the EP election was won by the urban-orientated USR-PLUS alliance by a large margin. At the presidential election, in Bucharest, both rounds were won by Iohannis. The analysis of the electoral geographies from these elections revealed an electoral polarized city and significant realignments in the electoral space in Bucharest between the two elections.

Although USR-PLUS won the most of votes in almost all locations, the electoral geography of the alliance was deeply polarized. The highest scores were clustered in socio-spatilities with younger, educated and wealthier population. These spaces are located mostly in the city centre, student campuses, northern low-density residential areas and some of the socialist housing estates located more to the inner ring of the city. Lower scores were recorded in places with poorer and more vulnerable social groups, where PSD did its best performance. PNL, which obtained a score close to PSD, recorded high scores both in the favorite socio-spatialities of PSD, colonizing the same space, but also in areas with richer populations or with less vulnerable population.

The presidential election was won by Iohannis. The spatial polarization present at the EP election was present also in November at the presidential run. In the first round, although Iohannis obtains high scores in the same peripheral places as PNL, the electoral geography of Iohannis has some differences from the one of PNL. For example, Iohannis highest scores are recorded in spaces where USR-PLUS achieved landslide victory. His electoral geography in the first round has a strong catch-all feature. Between the two rounds there was a realignment through which spaces more favorable towards USR-PLUS and Barna became hotspots of high scores of Iohannis. This structuration also explains the lower score of Barna in comparison with USR-PLUS. Iohannis colonized these spaces that were polarized against the spatial support of PSD. Higher scores of Barna were located, as it was for USR-PLUS, in spaces with younger, richer, educated social groups, but his electoral support decreased proportionally across the city. Dăncilă's electoral geography is consistent with the one of PSD in both rounds. In the second round, the electoral geographies of Iohannis and Dăncilă are placed in opposition. The spatial polarization for Iohannis 
is higher in the second round than the first. The realignment between the two rounds transforms again the geography of PNL candidate, because the higher scores are concentrated in the areas with younger, educated or wealthy population. The anti-PSD vote is prolonged in this second round as well, because Iohannis captures from the socio-spatiality of USR-PLUS and Dan Barna while also building an electoral geography in opposition to that of Viorica Dăncilă.

The paper explored the intricate patterns of association between the European election and the national politics and presidential election in Romania. The analysis revealed a strong connection between the European election and the national political arena, which is consistent with the literature on European elections. The European election held in Romania in May 2019 was deeply anchored in terms of political rhetorics, party campaigning and electoral behavior in the national Romanian political scene. The paper also contributes to the understanding of European election impact on subsequent elections within the national electoral cycle. Although there is a rich literature on the influence of national electoral cycle on European elections little is known on the role European elections play on other national elections. The Romanian case study revealed how a strong protest anti-governmental vote at European elections generated a decrease in interest for the Presidential elections held only some few months apart, which further points to the national character of European elections.

\section{References}

1. AGNEW, J. (1996) Mapping politics: how context counts in electoral geography. Political Geography, 15, pp. 129-146.

2. ANSELIN, L. (1995) Local Indicators of Spatial Association-LISA. Geographical Analysis, 27, pp. 93-115.

3. BENEDEK, J. and CRISTEA, M. (2014) Growth Pole Development and 'Metropolization' in Post-Socialist Romania. Studia Geographia UBB, 59 (2), pp. 125-138.

4. CAVALCANTI, M. (1997) Urban reconstructions and autocratic regimes: Ceausescu's Bucharest in its historic context. Planning Perspectives, 12 (1), pp. 71-109.

5. CREŢAN, R., O'BRIEN, T. (2020) Corruption and conflagration:(in) justice and protest in Bucharest after the Colectiv fire. Urban Geography, 41 (3), pp. 368-388.

6. GIUGĂL, A., JOHNSTON, R. and CONSTANTINESCU, S. (2011) Democratic Musical Chairs? Romania's Post-1989 Electoral Geography. Space and Polity, 15, pp. 143-161 
7. GRIFFITH, D. (1987) Spatial Autocorrelation: A Primer. Washington.

8. GUȚOIU, G. (2018) Electoral geography and the post-socialist city: Is the pre-world war II urban tissue still important? Evidence from Bucharest at the Romanian parliamentary elections of 2016. European Quarterly of Political Attitudes and Mentalities, 7 (3), pp. 4760 .

9. GUȚOIU, G. (2019a) The Urban Electoral Geographies of Cluj-Napoca, 1992-2016. Online Journal Modelling the New Europe, 29, pp. 108-135 .

10. GUȚOIU, G. (2019b) Spatial and Temporal Patterns of Polarization and Population Decline in Romania's Demography: 1992-2018. Revista Universitară de Sociologie, 15 (2), pp. 41-58.

11. HANLEY, S. and SIKK, A. (2014) Economy, Corruption or Floating voters? Explaining the Breakthroughs of Anti-Establishment Reform Parties in Eastern Europe. Party Politcs, $22(4)$, pp. 522-533.

12. HIX, S. and LORD, C. (1997) Political Parties in the European Union. Palgrave Macmillan.

13. HIX, S. and MARSH, M. (2007) Punishment or protest? Understanding European parliament elections. Journal of Politics, 69 (2), pp. 495-510.

14. HIX, S. and MARSH, M. (2011) Second-order effects plus pan-European political swings: An analysis of European Parliament elections across time. Electoral Studies, 30 (1), pp. 415.

15. ION, E. (2014) Public funding and urban governance in contemporary Romania: the resurgence of state-led urban development in an era of crisis. Cambridge Journal of Regions, Economy and Society, 7 (1), pp. 171-187.

16. JOHNSTON, R. and PATTIE, C. (2006) Putting Voters in their Place, New York: Oxford UP.

17. LEIB, J. and QUINTON, N. (2011) On the shores of the "moribund backwater"? Trends in electoral geography research since 1980. In: WARF, B. and LEIB, B. (eds): Revitalizing electoral geography. Farnham: Ashgate, pp. 9-27.

18. MAXIM, J. (2009) Mass housing and collective experience: on the notion of microraion in Romania in the 1950s and 1960s. The Journal of Architecture 14, pp. 7-26 
19. MAXIM, J. (2019) The Socialist Life of Modern Architecture: Bucharest, 1949-1964. New York:

Routledge.

MARCIŃCZAK, S. and HESS, D. (2019) Vertical segregation of apartment building dwellers during late state socialism in Bucharest, Romania. Urban Geography Open Access.

20. MARCIŃCZAK, S., GENTILE, M., RUFAT, S. and CHELCEA, L. (2014) Urban Geographies of Hesitant Transition: Tracing Socioeconomic Segregation in PostCeauşescu Bucharest. International Journal of Urban and Regional Research, 38 (4), pp. 1399-1417.

21. MIONEL, V. and NEGUȚ, S. (2011) The Socio-Spatial Dimension of Bucharest Ghettos. Transylvanian Review of Administrative Sciences, 33, pp. 197-217.

22. O'LOUGHLIN, J., FLINT, C. and ANSELIN, L. (1994) The Geography of the Nazi Vote: Context, Confession, and Class in the Reichstag Election of 1930. Annals of the Association of American Geographers, 84, pp. 351-380.

23. POP-ELECHEȘ, G. (1999) Separated at Birth or Separated by Birth? the Communist Successor Parties in Romania and Hungary. East European Politics and Societies, 13, pp. 117- 147.

24. POP-ELECHEȘ, G. (2008) A party for all seasons: Electoral adaptation of Romanian Communist successor parties. Communist and Post-Communist Studies, 41 (4), pp. $465-$ 479.

25. REIF, K. and SCHMITT, H. (1980) Nine Second-Order National Elections - A conceptual framework for the Analysis of European Election Results. European Journal of Political Research, 8, pp. 3-44.

26. RUFAT, S. and SUDITU, B. (2008) Bucarest, faire la ville entre héritages et mimétisme. L'Espace géographique, 37, pp.327-337.

27. SCHMITT, H. and TEPEROGLOU, E. (2015) The 2014 European Parliament elections in Southern Europe: second-order or critical elections? South European Society and Politics, 20 (3), pp. 287-309.

28. TOBLER, W. (1970) A computer movie simulating urban growth in the Detroit region. Economic Geography, 46, pp. 234-240. 
29. SIKK, A. (2012) Newness as a Winning Formula for New Political Parties. Party Politics, 18 (4), pp. 465-486.

30. ZARECOR, K. E. (2018). What Was So Socialist about the Socialist City? Second World Urbanity in Europe. Journal of Urban History, 44 (1), pp. 95-117. 